\title{
Pregenealogical Coherence dan Teks Awal Markus 1:41
}

\author{
Stefanus Kristianto* \\ *Penulis adalah alumni STAS, Surabaya (S.Th., 2008), STT Aletheia, Lawang (M.Div., 2010; M.Th., 2016) \\ dan Trinity Theological College, Singapore (M.Th., 2017), yang saat ini melayani sebagai rohaniwan di \\ GKA Trinitas, Surabaya. \\ Email: stefanuskristianto31@gmail.com
}

\begin{abstract}
Abstrak: Diskusi teks Markus 1:41 merupakan salah satu diskusi teks yang paling menarik. Mayoritas sarjana menganggap bahwa bacaan $\sigma \pi \lambda \alpha \gamma \chi \nu 1 \sigma \theta \varepsilon \grave{s}$ adalah bacaan sekunder, meskipun bacaan ini didukung oleh mayoritas saksi. Dalam tulisan ini, penulis akan menunjukkan bahwa bukti yang didapat dari analisis pregenealogical coherence makin memperkuat validitas bukti eksternal dalam mendukung bacaan $\sigma \pi \lambda \alpha \gamma \chi v i \sigma \theta \varepsilon i \zeta$ sebagai teks awal. Karena itu, bukti eksternal yang konklusif ini tidak boleh diabaikan begitu saja. Di akhir tulisan, penulis akan mendiskusikan secara singkat kemungkinan transkripsional (transcriptional probability) mengapa penyalin mengubah bacaan $\sigma \pi \lambda \alpha \gamma \chi v i \sigma \theta \varepsilon i \varsigma$ menjadi ỏ $\rho \gamma \imath \theta \varepsilon i ́ s$.

Kata-kata kunci: Kritik Teks Perjanjian Baru, Pregenealogical Coherence, Coherence-Based Genealogical Method, Markus 1:41, Teks Awal
\end{abstract}

Abstract: Discussion as to the text of Mark 1:41 is one of the most interesting textual discussions. Although most witnesses support the primacy of the reading $\sigma \pi \lambda \alpha \gamma \chi v i \sigma \theta \varepsilon i \varsigma$, most scholars consider that the reading is secondary. In this paper, the writer intends to show that the pregenealogical coherence analysis on the text strengthens the validity of the external evidences in supporting $\sigma \pi \lambda \alpha \gamma \chi v i \sigma \theta \varepsilon i \varsigma$ as the initial text. These conclusive external evidences, therefore, must not be set aside. At the end of this paper, the writer will discuss in brief as to why the scribes altered the reading $\sigma \pi \lambda \alpha \gamma \chi v i \sigma \theta \varepsilon i \varsigma$ to be

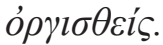

Keywords: New Testament Textual Criticism, Pregenealogical Coherence, Coherence-Based Genealogical Method, Mark 1:41, Initial Text 


\section{Pendahuluan}

Markus 1:41 merupakan salah satu teks yang paling menarik dalam diskusi kritik teks Perjanjian Baru. Terkait teks ini, para kritikus teks dihadapkan pada dua pilihan bacaan mengenai respons Yesus terhadap seorang kusta yang meminta-Nya untuk menyembuhkannya. Mayoritas saksi memiliki bacaan "Yesus berbelas kasihan ( $\sigma \pi \lambda \alpha \gamma \chi \nu 1 \sigma \theta \varepsilon i \varsigma)$ " terhadap orang itu, sementara segelintir saksi lain memiliki bacaan "Yesus marah

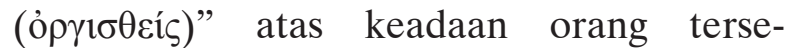
but. ${ }^{1}$ Apa yang menarik dalam diskusi ini ialah bahwa sebagian besar sarjana cenderung memilih bacaan ỏ $\rho \gamma \sigma \theta \varepsilon i ́ s$ sebagai teks awal (initial text), ${ }^{2}$ meskipun mayoritas saksi

'Para penafsir yang menerima bacaan "Yesus marah" sebagai bacaan yang lebih awal, sebenarnya menyadari bahwa teks tidak memberitahu alasan kemarahan Yesus. Karena itu, mereka mengusulkan beberapa penjelasan mengenai kemarahan Yesus. Beberapa di antaranya: Yesus marah karena orang kusta ini mendekati-Nya (sehingga berpotensi membuat-Nya najis), Yesus marah karena perjalanan-Nya diganggu oleh orang tersebut, dan Yesus marah karena orang ini tampaknya meragukan Yesus. Di antara beragam penjelasan yang ditawarkan, mayoritas sarjana yang menerima orisinalitas bacaan 'Yesus marah' memahami kemarahan Yesus di sini terkait dengan kuasa kejahatan di dunia: Dia marah karena kuasa kejahatan telah merusak keadaan dan kehidupan orang tersebut.

${ }^{2}$ Sejak sekitar dua dekade lalu, beberapa kritikus teks mulai mempertanyakan tujuan klasik dari disiplin kritik teks, yang adalah merekonstruksi teks asli seoptimal mungkin. Para kritikus ini berpendapat bahwa merekonstruksi teks asli merupakan tugas yang tampaknya mustahil untuk dilakukan. Karena itu, tujuan ini sepertinya perlu ditinggalkan. Lihat misalnya Eldon J. Epp, "Multivalence of the Term 'Original Text' in New Testament Textual Criticism," Harvard Theological Review 92 (1999): 245-81; David C. Parker, The Living Text of the Gospels (Cambridge: CUP, 1997). Meski demikian, beberapa sarjana lain tetap berupaya mempertahankan validitas tujuan klasik ini, di antaranya Holger Strutwolf, "Original Text and Textual History," dalam Klaus Wachtel dan Michael W. Holmes, eds., The Textual History of the Greek New Testament: Changing Views in Contemporrary Research (Atlanta: SBL, 2011), 23-41; Paul Ellingworth, "Text, Translation, and Theology: The New Testament in the Original Greek?" Filologia Neotestamentaria 13/25-26 (2000): 61-73; dan Daniel B. Wallace, "Challenges in New Testament Textual Criticism for the Twenty-First Century," Journal of Evangelical Theological Society 52/1 (March 2009): 79-100.

Dalam konteks debat ini, Gerd Mink menemukan sebuah istilah yang baru, yakni 'teks awal' (Ausgangstext atau initial text). Istilah ini kurang lebih merujuk pada rekonstruksi teks terawal yang bisa dicapai, yang darinya transmisi teks dimulai. Di tengah perdebatan tadi, istilah sebenarnya mendukung $\sigma \pi \lambda \alpha \gamma \chi v 1 \sigma \theta \varepsilon i \varsigma$ sebagai bacaan yang lebih autentik.

Bart Ehrman adalah salah seorang pembela

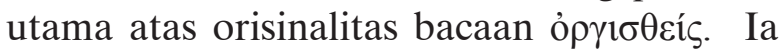
menganggap bahwa bacaan $\sigma \pi \lambda \alpha \gamma \chi v i \sigma \theta \varepsilon i \varsigma$ tidak mungkin menjadi bacaan yang lebih awal karena dua alasan. Pertama, Ehrman berpendapat bahwa bacaan ỏ $\rho \gamma 1 \sigma \theta \varepsilon i ́ c$ adalah bacaan yang lebih sulit. Menurutnya, lebih mudah memahami bahwa penyalin mengubah keterangan yang negatif mengenai emosi Yesus menjadi lebih positif, ketimbang mengubah yang positif itu menjadi negatif. Karena itu, bila kanon lectio difficilior potior ("bacaan yang lebih sulit merupakan bacaan yang lebih disukai") diikuti secara konsisten, maka tentu

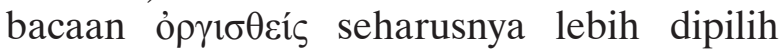
ketimbang $\sigma \pi \lambda \alpha \gamma \chi v i \sigma \theta \varepsilon i \zeta . ~ K e d u a$, Ehrman melihat bahwa Matius dan Lukas, yang menggunakan Markus sebagai vorlage, ternyata menghilangkan informasi ini. Jika memang

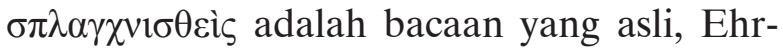
man mempertanyakan mengapa Matius dan Lukas perlu menghilangkan informasi yang positif ini? Menurutnya, hilangnya bacaan ini dalam Injil Matius dan Injil Lukas sebenarnya mengindikasikan bahwa kedua penulis Injil ini mengalami kesulitan dengan vorlage mereka. Karena dua alasan ini, Ehrman akhirnya menyimpulkan bahwa bacaan $\sigma \pi \lambda \alpha \gamma \chi \nu 1 \sigma \theta \varepsilon i \varsigma$

ini ternyata bisa menjadi titik temu bagi kedua kubu yang berbeda pandangan (bdk. kesimpulan Michael W. Holmes, "From 'Original Text' to 'Initial Text': The Traditional Goal of New Testament Textual Criticism in Contemporary Discussion," dalam Bart D. Ehrman dan Michael W. Holmes, eds., The Text of the New Testament in Contemporary Research: Essays on the Status Quaestionis. NTTSD 42 (Leiden: Brill, 2013), 637-88), meski tentu saja mereka memahami istilah ini secara berbeda. Bagi kubu revisionis, 'teks awal' bukan merujuk pada teks penulis (authorial text), tetapi teks paling awal (yang mungkin saja jauh berbeda dari teks penulis) yang darinya transmisi teks dimulai (lihat misalnya David C. Parker, "Is "Living Text" Compatible with "Initial Text"? Editing the Gospel of John," dalam Wachtel dan Holmes, The Textual History of the Greek New Testament, 13-21). Sementara bagi kubu klasik, tidak ada alasan untuk membedakan teks awal dari teks penulis.

Meskipun penulis masih memercayai mungkinnya merekonstruksi teks asli sebagian besar teks Perjanjian Baru, untuk alasan netralitas, penulis akan lebih banyak menggunakan istilah teks awal dalam diskusi ini (meski sesekali penulis akan tetap memberi penekanan soal orisinalitas). 
sebenarnya adalah bacaan yang sekunder, yang muncul dalam konteks polemik antara kekristenan dengan kaum pagan. ${ }^{3}$

Seperti yang disebutkan sebelumnya, Ehrman sebenarnya tidak sendiri. Banyak penafsir sependapat dengannya dalam memilih ỏ $\gamma 1 \sigma \theta \varepsilon i ́ s$ sebagai teks awal. Morna Hooker, misalnya, menulis, "It is easy to see why translators prefer the majority text-but, for precisely that reason, it seems that the minority text is more likely to be correct; scribes might well have changed a statement that Jesus felt anger to one that he felt compassion, but it is difficult to see why they should have made the opposite change." 4 Senada dengan Hooker dan Ehrman, James Brooks juga berpendapat, "Despite the massive external attestation for 'filled with compassion,' internal considerations are so strong that 'having become angry' probably is the original." "Selain ketiga sarjana ini, R.T. France, James Edwards, Joel Marcus, dan editor SBLGNT (Michael Holmes) juga memiliki pendapat yang sama. ${ }^{6}$ Bahkan, menariknya, Daniel Wallace, yang biasanya berseberangan dengan Ehrman dalam banyak hal, kali ini juga sepakat dengan Ehrman

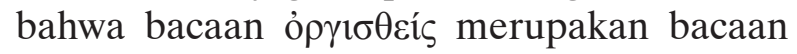
yang lebih autentik. ${ }^{7}$

${ }^{3}$ Bart D. Ehrman, "A Leper in the Hand of an Angry Jesus," dalam Studies in the Textual Criticism of the New Testament (Leiden: Brill, 2006), 120-41; idem, Misquoting Jesus: The Story behind Who Changed the Bible and Why (San Francisco: HarperSanFrancisco, 2005), 133-9.

${ }^{4}$ Morna D. Hooker, The Gospel According to Saint Mark. BlackNTC (Peabody: Hendrickson, 1991), 79. Penekanan oleh penulis.

${ }^{5}$ James A. Brooks, Mark. NAC (Nashville: Broadman \& Holman, 2001), 55. Penekanan oleh penulis.

${ }^{6}$ Lihat R.T. France, The Gospel of Mark. NIGTC (Grand Rapids/Carlisle: Eerdmans/Paternoster, 2002), 115; James R. Edwards, The Gospel According to Mark. PNTC (Grand Rapids/Leicester: Eerdmans/Apollos, 2002), 70; Joel Marcus, Mark 1-8: A New Translation with Introduction and Commentary. AnchorBib; New Haven/London: YUP, 2008), 206; Michael W. Holmes, ed., The Greek New Testament: SBL Edition (Atlanta/Bellingham, WA: SBL/Logos, 2010), 69.

${ }^{7}$ Daniel B. Wallace, "The Gospel According to Bart: A Review Article of Misquoting Jesus by Bart Ehrman," Journal of the Evangelical Theological Society 49/2 (2006): 340-2.
Bertolak dari fakta di atas, dalam tulisan ini, penulis akan mencoba membahas problem teks Markus 1:41 dengan memberi perhatian khusus pada aspek pregenealogical coherence saksi-saksi pendukung masing-masing bacaan. Penulis akan menunjukkan bahwa koherensi saksi-saksi pendukung bacaan $\sigma \pi \lambda \alpha \gamma \chi v i \sigma \theta \varepsilon i \varsigma$ ternyata jauh lebih baik dibandingkan koherensi saksi-saksi pendukung bacaan ỏ $\rho \gamma \_\theta \varepsilon i ́ s$. Ini berarti bukti eksternal yang mendukung keutamaan bacaan $\sigma \pi \lambda \alpha \gamma \chi \nu 1 \sigma \theta \varepsilon i \varsigma$ makin dikuatkan. Implikasinya, bukti eksternal yang sangat konklusif ini tentunya tidak boleh diabaikan begitu saja. Setelah itu, penulis akan mendiskusikan secara singkat penjelasan yang mungkin mengapa penyalin mengubah bacaan $\sigma \pi \lambda \alpha \gamma \chi \nu 1 \sigma \theta \varepsilon i \varsigma$ yang lebih mudah menjadi bacaan ỏ $\gamma \_\sigma \theta \varepsilon i ́ \varsigma$ yang lebih sulit.

\section{Sekilas Mengenal Coherence-Based Genealogical Method}

Sekitar awal tahun tujuh puluhan, Eldon Epp menerbitkan sebuah artikel (yang semula dipresentasikannya dalam Hatch Memorial Lecture) yang mengkritisi perkembangan dalam studi kritik teks Perjanjian Baru. Ia mengumpamakan keadaan dalam studi teks Perjanjian Baru waktu itu layaknya sebuah interlude dalam bermusik. ${ }^{8}$ Ia tidak menyangkal bahwa ada banyak aktivitas yang dilakukan dalam studi kritik teks Perjanjian Baru, tetapi ia melihat studi ini belum menghasilkan pencapaian yang signifikan sejak masa Wetscott dan Hort. ${ }^{9}$ Dalam tulisan tersebut ada beberapa hal yang dikritisi Epp, yakni kurangnya kemajuan dalam edisi kritikal teks Yunani, ${ }^{10}$ kurang kemajuan dalam hal teori dan sejarah teks terawal Perjanjian Baru, ${ }^{11}$ kurangnya

${ }^{8}$ Eldon J. Epp, “The Twentieth Century Interlude in New Testament Textual Criticism," Journal of Biblical Literature 93 (1974): 386-414. Diterbitkan ulang dalam Eldon J. Epp dan Gordon D. Fee, Studies in the Theory and Method of New Testament Textual Criticism (Grand Rapids: Eerdmans, 1993), 83-108. Referensi di sini menggunakan versi terbitan ulang.

${ }^{9} \mathrm{Epp}$, “The Twentieth Century Interlude in New Testament Textual Criticism," 83-4.

${ }^{10}$ Ibid., 84-7.

${ }^{11}$ Ibid., 87-96. 
perkembangan apparatus (catatan kaki) dalam Editio Critica Maior, ${ }^{12}$ kurangnya kemajuan dalam hal evaluasi bacaan, ${ }^{13}$ maupun kecenderungan beberapa sarjana untuk kembali ke Textus Receptus. ${ }^{14}$ Meski demikian, Epp menutup tulisannya dengan melihat adanya peluang perkembangan di masa depan. Di antaranya, dia melihat bahwa metode kuantitatif dan penggunaan komputer tampaknya berpotensi membawa kemajuan yang signifikan bagi perkembangan studi teks Perjanjian Baru ke depannya. ${ }^{15}$

Optimisme Epp tidak salah. Di awal milenium ini, dia mengakui bahwa ada cukup banyak kemajuan yang signifikan dalam studi kritik teks Perjanjian Baru. ${ }^{16}$ Di antara beragam kemajuan itu, salah satu yang cukup mengemuka ialah munculnya pendekatan baru dalam studi teks Perjanjian Baru. Mulai tahun 1980an, Gerd Mink mengembangkan sebuah pendekatan baru dalam studi teks Perjanjian Baru, yang kini disebut sebagai metode Münster atau lebih lazim dikenal sebagai Coherence-Based Genealogical Method (CBGM) ${ }^{17}$ Sederhananya, Wasserman dan Gurry mendefinisikan metode CBGM ini sebagai "a method that (1) uses a set of cumputer tools (2) based in a new way of relating manuscript texts that is (3) designed to help us understand the origin and history of

\footnotetext{
${ }^{12}$ Ibid., $96-8$

${ }^{13}$ Ibid., 98-9.

${ }^{14}$ Ibid., 100.

${ }^{15}$ Ibid., 101-4, 106-7.
}

${ }^{16}$ Eldon J. Epp, "Issues in New Testament Textual Criticism: Moving from the Nineteenth Century to the Twenty-First Century," dalam David A. Black, ed., Rethinking New Testament Textual Criticism (Grand Rapids: Baker, 2002), 19.

${ }^{17}$ Untuk pengantar singkat terhadap metode ini, lihat Tommy Wasserman dan Peter Gurry, A New Approach to Textual Criticism: An Introduction to the Coherence-Based Genealogical Method (Atlanta/Stuttgart: SBL/Deutsche Bibelgesellschaft, 2017), 17-35; lihat juga tulisan Gerd Mink sendiri, "Contamination, Coherence, and Coincidence in Textual Transmission: The Coherence-Based Genealogical Method (CBGM) as a Compliment and Corrective to Existing Approach," dalam Wachtel dan Holmes, The Textual History of the Greek New Testament, 141-216. the New Testament text."18 Jadi, seperti yang Epp harapkan, metode ini mengombinasikan pendekatan kuantitatif dan juga penggunaan komputer.

Dalam menganalisis relasi teks, metode ini memberi perhatian khusus pada dua tipe koherensi. Tipe pertama disebut sebagai pregenealogical coherence. Di dalam fase ini, kritikus teks berupaya menemukan kesamaan teks antarsaksi yang diwujudkan dalam bentuk persentase. Untuk menemukan koherensi teks antarsaksi dalam konteks korpus Injil Sinoptik, kritikus teks bisa menggunakan perangkat daring Parallel Pericopes: Manuscripts Clusters ${ }^{19}$ atau Parallel Pericopes: Find Relatives. ${ }^{20}$ Sedangkan bila mereka hendak menguji koherensi teks saksi-saksi Surat-surat Umum, mereka bisa menggunakan perangkat daring Potential Ancestors and Descendants. ${ }^{21}$ Asumsi mendasar dari tahap ini ialah bahwa semakin besar persentase koherensi teks, berarti semakin baik teks tersebut ditransmisikan oleh para saksi. ${ }^{22}$

Tipe koherensi selanjutnya disebut sebagai genealogical coherence. Bila dalam tahap sebelumnya, kritikus teks hanya berupaya menemukan kesamaan teks antarsaksi, maka dalam tahap ini, kritikus teks mencoba melihat bentuk relasi antarteks dalam bentuk 'diagram aliran teks' (textual flow diagram): apakah A merupakan pendahulu $\mathrm{B}(\mathrm{A} \rightarrow \mathrm{B})$, atau $\mathrm{A}$ merupakan turunan $\mathrm{B}(\mathrm{A} \leftarrow \mathrm{B})$ atau $\mathrm{A}$ memiliki relasi yang tidak jelas dengan $\mathrm{B}(\mathrm{A}-$ ? B). Perangkat daring utama yang digunakan dalam fase ini ialah Coherence in Attestation ${ }^{23}$

\footnotetext{
${ }^{18}$ Wasserman dan Gurry, A New Approach to Textual Criticism, 3.

${ }^{19}$ Bisa diakses di http://intf.uni-muenster.de/TT_PP/PP Clusters.html

${ }^{20}$ Bisa diakses di http://intf.uni-muenster.de/PreCo/Coh1 PP.html.

${ }^{21}$ Bisa diakses di http://intf.uni-muenster.de/cbgm2/ PotAnc5.html

${ }^{22}$ Wasserman dan Gurry, "A New Approach to Textual Criticism," 37-58.
}

${ }^{23}$ Bisa diakses di http://intf.uni-muenster.de/cbgm2/ Coh1_4.html 
atau Coherence at Variant Passages. ${ }^{24}$ Asumsi dasar dalam fase ini ialah semakin konsisten sebuah kelompok varian (attestation), maka semakin besar kemungkinan teks yang dikandung kelompok tersebut lebih mewakili teks asli, atau setidaknya teks awal. ${ }^{25}$

Meskipun metode ini dianggap cukup menjanjikan, metode ini sebenarnya masih memiliki beberapa hal yang perlu dibenahi. Sebagai metode yang relatif baru, tentu saja ada satu dua hal yang perlu lebih dioptimalkan di sana dan di sini. ${ }^{26}$ Selain itu, metode ini juga belum bisa diterapkan pada semua korpus Perjanjian Baru. Perangkat daring untuk menguji pregenealogical coherence baru bisa digunakan untuk meneliti koherensi saksisaksi Injil Sinoptik dan Surat-surat Umum, dan belum bisa digunakan untuk menguji koherensi saksi-saksi Injil Yohanes maupun Surat-surat Paulus. Sedangkan untuk perangkat penguji genealogical coherence, sejauh ini baru bisa digunakan untuk meneliti relasi saksi-saksi Kisah Para Rasul dan Surat-surat Umum dalam Perjanjian Baru. Meski demikian-meski ada sedikit kekurangan di sanasini-tidak bisa dipungkiri bahwa metode ini sebenarnya telah membawa dampak yang signifikan bagi studi Perjanjian Baru secara umum, sebab metode ini telah membuat editor $\mathrm{NA}^{28}$ dan $\mathrm{UBS}^{5}$ mengubah teks kritikal mereka di beberapa bagian, khususnya dalam Surat-surat Umum (mis. Yak. 1.20; 2.15; 1Ptr. 4.16, 2Ptr. 3.10, dsb). ${ }^{27}$

\footnotetext{
${ }^{24}$ Bisa diakses di http://intf.uni-muenster.de/cbgm2/ Coh2_2.html

${ }^{25}$ Wasserman dan Gurry, "A New Approach to Textual Criticism," 59-93.

${ }^{26}$ Lihat kritik dan saran perbaikan Wasserman dan Gurry dalam ibid., 111-21. Lihat juga beberapa catatan penulis dalam "Resensi Buku A New Approach to Textual Criticism: An Introduction to the Coherence-Based Genealogical Coherence" Jurnal Theologia Aletheia 20/15 (terbit September 2018).
}

${ }^{27}$ Untuk daftar lengkapnya, lihat bagian pengantar $\mathrm{NA}^{28}, 50-1$

\section{Pregenealogical Coherence Saksi-saksi Markus 1:41}

Seperti yang sudah dijelaskan sebelumnya, metode CBGM secara keseluruhan belum bisa diterapkan dalam semua kitab Perjanjian Baru. Sejauh ini, perangkat genealogical coherence baru bisa digunakan untuk studi Kisah Para Rasul dan Surat-surat Umum saja. $^{28}$ Karena itu dalam tulisan ini, penulis hanya akan berfokus hanya pada aspek pregenealogical coherence untuk menganalisis teks Markus 1:41.

Dari apparatus $\mathrm{NA}^{28}$ dan $\mathrm{UBS}^{5}$ terlihat bahwa bacaan $\sigma \pi \lambda \alpha \gamma \chi \nu 1 \sigma \theta \varepsilon i s$ didukung oleh mayoritas teks Yunani, antara lain 01, 02, 03, 04, 019, 032, 037, 038, 0130, 0233, 28, 33, 157, 180, 205, 565, 579, 597, 700, 892, 1006, 1010, 1071, 1241, 1243, 1292, 1342, 1424, 1505, 2427 dan seluruh teks Byzantine. Dengan menggunakan perangkat daring Parallel Pericopes: Manuscript Clusters dihasilkan data sebagai berikut: ${ }^{29}$

\footnotetext{
${ }^{28}$ Untuk contoh studi teks dengan menggunakan genealogical coherence dalam membuat keputusan tekstual, lihat Wasserman dan Gurry, "A New Approach to Textual Criticism," 70-90; lihat juga David C. Parker, Textual Scholarship and the Making of the New Testament (Oxford: OUP, 2012), 84-93.

${ }^{29}$ Ada dua hal yang perlu diingat di sini. Pertama, untuk menggunakan perangkat daring Parallel Pericopes: Manuscript Clusters, nama saksi yang digunakan ialah penomoran ala Gregory-Aland dan bukan simbol huruf. Kedua, peringkat yang ditulis di sini disamakan dengan daftar yang dihasilkan perangkat, yang sebenarnya mengikutsertakan juga perbandingan naskah dengan initial text hasil rekonstruksi editor (A). Akibatnya, peringkat koherensi beberapa saksi sebenarnya bisa jadi jauh lebih tinggi. Sebagai contoh, kerabat terdekat nomor 2 dari 01 ialah 03. Akan tetapi, karena perangkat menyatakan bahwa kerabat terdekat 01 adalah A, maka bisa dikatakan bahwa sebenarnya kerabat terdekat 01 ialah 03 .
} 


\begin{tabular}{|c|c|c|c|c|}
\hline SAKSI & $\begin{array}{c}\text { KERABAT TERDEKAT } \\
\text { DENGAN BACAAN } \\
\sigma \pi \lambda \alpha \gamma \chi v i \sigma \theta \varepsilon i \varsigma\end{array}$ & $\begin{array}{l}\text { PERSENTASE } \\
\text { (RANKING) }\end{array}$ & 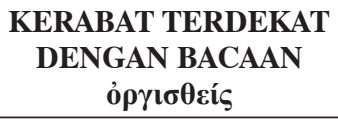 & $\begin{array}{c}\text { PERSENTASE } \\
\text { (RANKING) }\end{array}$ \\
\hline 01 & 03 & $84.9(2)$ & - & - \\
\hline 02 & - & - & - & - \\
\hline 03 & 892 & $85.5(2)$ & - & - \\
\hline 04 & $037(3-89.0)^{30}$ & $86.6(11)$ & - & - \\
\hline 019 & 892 & $88.0(2)$ & - & - \\
\hline 032 & - & - & - & - \\
\hline 037 & - & - & - & - \\
\hline 038 & 565 & $85.1(1)$ & & \\
\hline 0130 & $\mathrm{~N} / \mathrm{A}$ & N/A & N/A & N/A \\
\hline 0233 & 1071 & $90.5(19)$ & - & - \\
\hline 28 & $*$ & 87.2 & $*$ & $*$ \\
\hline 33 & $892(03-85.5)$ & $85.4(1)$ & - & - \\
\hline 157 & $*$ & 90.3 & $*$ & $*$ \\
\hline 180 & $\mathrm{~N} / \mathrm{A}$ & N/A & $\mathrm{N} / \mathrm{A}$ & N/A \\
\hline 205 & - & - & - & - \\
\hline 565 & $*$ & 87.9 & $*$ & $*$ \\
\hline 579 & $33(033-84.8)$ & $82.1(2)$ & - & - \\
\hline 597 & N/A & N/A & N/A & N/A \\
\hline 700 & $*$ & 87.8 & $*$ & $*$ \\
\hline 892 & 019 & $88.0(2)$ & - & - \\
\hline 1006 & N/A & N/A & N/A & N/A \\
\hline 1010 & N/A & N/A & N/A & N/A \\
\hline 1071 & - & - & - & - \\
\hline 1241 & - & - & - & - \\
\hline 1243 & N/A & N/A & N/A & N/A \\
\hline 1292 & N/A & N/A & N/A & N/A \\
\hline 1342 & $*$ & $*$ & $*$ & $*$ \\
\hline 1424 & - & - & - & - \\
\hline 1505 & N/A & N/A & N/A & N/A \\
\hline 2427 & N/A & N/A & N/A & N/A \\
\hline
\end{tabular}

Penulis memberikan tanda garis atau dash (-) untuk menandakan bahwa dalam daftar yang dihasilkan oleh perangkat daring, tidak ditemukan adanya kerabat dekat yang mengandung bacaan yang dimaksud. Tanda bintang atau asteriks (*) menunjukkan bahwa saksi yang bersangkutan tidak memiliki kerabat dekat yang persentase koherensinya lebih besar daripada perbandingan saksi tersebut

\footnotetext{
${ }^{30}$ Maksud bagian ini ialah bahwa saksi 04 memiliki koherensi dengan naskah saksi 037, tetapi koherensi tertinggi saksi 037 bukan dengan naskah saksi 04 tetapi dengan saksi lain (minuskul 3).
}

dengan Majority Text (MT). Sebagai catatan, perangkat daring Parallel Pericopes: Manuscript Clusters hanya menampilkan kerabat dekat yang persentase koherensinya lebih tinggi daripada persentase perbandingan saksi tersebut dengan MT. Sebagai contoh, 038 memiliki persentase koherensi paling tinggi dengan 565 (85.1 persen). Akan tetapi, persentase tersebut ternyata tidak lebih besar daripada persentase koherensi 565 dengan MT, yang mencapai 87.9 persen. Akibatnya, perangkat daring tersebut tidak 
mengeluarkan data apa pun selain MT ketika nama 565 dimasukkan. Dengan kata lain, tanda asteriks dalam daftar di atas sebenarnya menunjukkan bahwa kerabat terdekat saksi tersebut ialah MT. Terakhir, simbol (N/A) menandakan bahwa perangkat Parallel Pericopes: Manuscript Clusters tidak (atau belum) memiliki data mengenai saksi tersebut.

Dari data di atas terlihat bahwa koherensi bacaan $\sigma \pi \lambda \alpha \gamma \chi v i \sigma \theta \varepsilon i \varsigma$ bisa dikatakan cukup baik. Dari dua puluh satu saksi $\sigma \pi \lambda \alpha \gamma \chi v i \sigma \theta \varepsilon i \varsigma$ yang datanya dimiliki oleh perangkat daring Parallel Pericopes: Manuscript Clusters,${ }^{31}$ sembilan di antaranya memiliki koherensi yang tinggi satu sama lain (01, 03, 04, 019, 038, 0233, 33, 579, 892). Namun, bila saksi-saksi yang kerabat terdekatnya adalah MT disertakan $(28,157,565,700,1342)$, maka jumlah ini meningkat menjadi empat belas. Ini berarti sebenarnya hanya tujuh saksi yang tidak memiliki koherensi satu sama lain. Jumlah ini tentu jauh lebih baik dibanding saksi yang

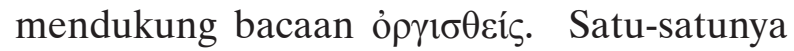
naskah Yunani yang mendukung bacaan ini ialah 05 (Codex Bezae Cantabrigiensis). Problemnya, 05 merupakan saksi yang unik (bila bukan eksentrik), sebab koherensinya terhadap semua saksi termasuk yang paling rendah. Dalam konteks Injil Sinoptik, koherensi tertinggi saksi ini ialah dengan A dan hanya sebesar 72.4 persen. $^{32}$ Lebih menarik lagi, beberapa kerabat terdekat saksi ini justru

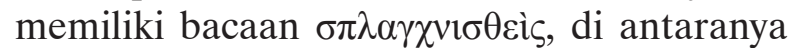
565 (nomor 11, 70.3 persen), 03 (nomor 15, 70.1 persen), 892 (nomor 18, 70.1 persen), 700 (nomor 20, 70 persen).

Sebagaimana yang disebutkan sebelumnya, asumsi dasar dalam analisis pregenealogical coherence ialah bahwa semakin besar

\footnotetext{
${ }^{31}$ Seperti yang terlihat di atas, dari tiga puluh saksi, data dari sembilan di antaranya tidak dimiliki oleh database perangkat daring $(0130,180,597,1006,1010,1243$, $1292,1505,2427)$. Karena itu, sembilan saksi ini bisa diabaikan.

${ }^{32}$ Dalam konteks Kisah Para Rasul, Wasserman dan Gurry mencatat bahwa rata-rata koherensi 05 dibanding naskah saksi lain termasuk sangat rendah, hanya sekitar 66 persen. Lihat Wasserman dan Gurry, A New Aprroach to Textual Criticism, 27.
}

persentase koherensi teks berarti semakin baik teks tersebut ditransmisikan. Dari sini terlihat bahwa besar kemungkinan 05 tidak mentransmisikan teks dengan baik. Selain karena persentasenya terhadap semua saksi cenderung sangat rendah, kerabat terdekat saksi ini justru memiliki bacaan yang berbeda. Dengan kata lain, berdasar analisis pregenealogical coherence, bacaan ỏ $\rho \gamma 1 \sigma \theta \varepsilon i ́ s$ bukanlah bacaan yang ditransmisikan dengan baik. Sebaliknya, bacaan $\sigma \pi \lambda \alpha \gamma \chi v i \sigma \theta \varepsilon i \varsigma$ justru didukung oleh saksi-saksi yang memiliki koherensi yang cukup baik satu sama lain. Apa yang bisa disimpulkan dari pembahasan ini ialah bahwa analisis pregenealogical coherence membuat bukti eksternal menjadi sangat konklusif dalam mendukung bacaan $\sigma \pi \lambda \alpha \gamma \chi v i \sigma \theta \varepsilon i \zeta$ sebagai bacaan yang lebih mungkin mencerminkan teks asli atau initial text. Karena itu, bukti yang sangat kuat ini tidak boleh dikesampingkan begitu saja.

\section{Analisis Perubahan}

Meski bukti eksternal secara konklusif mendukung orisinalitas bacaan $\sigma \pi \lambda \alpha \gamma \chi v ı \sigma \theta \varepsilon i \zeta$, dua pertanyaan masih tersisa. Pertama, bila memang $\sigma \pi \lambda \alpha \gamma \chi \nu 1 \sigma \theta \varepsilon i \varsigma_{\zeta}$ merupakan bacaan yang asli, mengapa Matius dan Lukas menghilangkan keterangan positif ini? Pertanyaan ini sebenarnya merupakan pertanyaan yang spekulatif dan kompleks, sebab jawabannya akan sangat bergantung pada hipotesa seseorang mengenai Synoptic Problems dan solusinya. Jawaban seseorang yang menganut Augustinian Hypothesis, misalnya, tentu akan berbeda dari mereka yang menganut hipotesa Oxford atau hipotesa Farrer. Dengan kata lain, pertanyaan ini sebenarnya merupakan sebuah pertanyaan hipotesis yang berdiri di atas hipotesa lain. Karena alasan ini, tidak heran beberapa sarjana berpendapat bahwa relasi dengan Matius dan Lukas harus dikesampingkan dalam diskusi bukti eksternal mengenai teks ini. ${ }^{33}$

\footnotetext{
${ }^{33}$ Peter J. Williams, “An Examination of Ehrman's Case

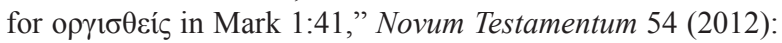
4; Edgar B. Ebojo, "Men, Manuscripts, and Mercy: Searching a Merciful God amongst the Variants," 8-9, n. 43 (makalah yang tidak diterbitkan, disampaikan dalam Bible Research Seminar di AGST Filipina 2016).
} 
Selain pertanyaan tersebut, pertanyaan lain yang perlu dijawab ialah: bila memang bacaan $\sigma \pi \lambda \alpha \gamma \chi \nu 1 \sigma \theta \varepsilon i \varsigma$ merupakan bacaan yang lebih awal, lantas mengapa penyalin Alkitab mengubahnya menjadi bacaan yang lebih sulit? Ada beragam solusi yang ditawarkan mengenai hal ini. Salah satu yang cukup terkemuka ialah

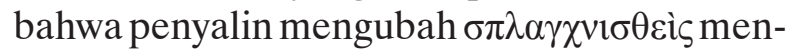

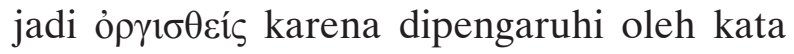
$\dot{\varepsilon} \mu \beta \rho \mu \eta \sigma \alpha ́ \mu \varepsilon v o \varsigma$ di ay. 43. ${ }^{34}$ Bila $\sigma \pi \lambda \alpha \gamma \chi v i \sigma \theta \varepsilon i \varsigma$ merupakan bacaan yang asli, memang akan menjadi susah dipahami mengapa Yesus yang "berbelas kasihan" di ay. 41 tiba-tiba mengusir orang yang baru disembuhkannya dengan kemarahan. Sebaliknya, pengusiran di ay. 43 ini akan lebih mudah dipahami bila sejak awal Yesus memang menunjukkan sikap yang bernada tidak senang terhadap orang tersebut. Dengan kata lain, beberapa penafsir meng-

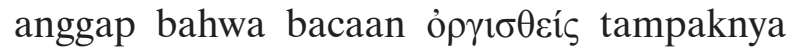
merupakan bacaan yang lebih mudah (mengingat kaitannya dengan ay. 43), sebab lebih sejalan dengan konteks cerita.

Meskipun cukup mengemuka, sayangnya argumen ini memiliki problem serius. Salah satunya, bila memang bacaan $\sigma \pi \lambda \alpha \gamma \chi v i \sigma \theta \varepsilon i \varsigma$ merupakan bacaan yang asli, mengapa penyalin justru mengubah bacaan ini dan bukan bacaan $\varepsilon \dot{\varepsilon} \beta \rho \varphi \mu \eta \sigma \alpha ́ \alpha \varepsilon v o \varsigma$ di ay. 43? Bukankah jauh lebih mudah mempertahankan gambaran Yesus yang berbelas kasih (dengan mengubah atau menghilangkan bacaan $\dot{\varepsilon} \mu \beta \rho \mu \eta \sigma \alpha ́ \mu \varepsilon v o \varsigma)$ ketimbang mengubah sosok Yesus menjadi pemarah sejak awal kisah (dengan mengubah $\sigma \pi \lambda \alpha \gamma \chi v 1 \sigma \theta \varepsilon i \varsigma)$ ? ${ }^{35}$

Di antara berbagai proposal lain, penulis melihat bahwa sampai sejauh ini solusi yang ditawarkan Peter Williams adalah proposal terbaik untuk menjelaskan perubahan ini. Ia

\footnotetext{
${ }^{34}$ Misalnya Larry W. Hurtado, Mark. NIBC (Peabody: Hendrickson, 1989), 33; Bruce M. Metzger, A Textual Commentary on the Greek New Testament $2^{\text {nd }}$ Edition (London/New York: UBS, 1994), 65; Tan Kim Huat, The Gospel According to Mark. Asia Bible Commentary (Manila: Asia Theological Association, 2011), 44.

${ }^{35}$ Bdk. juga kritik Ehrman dalam "A Leper in the Hand of an Angry Jesus," 127-8, meskipun penulis tidak menganggap semua argumen Ehrman di sana adalah argumen yang valid.
}

berpendapat bahwa kemungkinan besar perubahan ini terjadi karena kesilapan dalam penyalinan. ${ }^{36}$ Analisis ini didukung oleh dua hal. Pertama, ada kemiripan bentuk hurufhuruf yang menyusun kedua kata tersebut

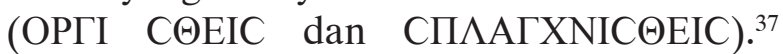
Selain enam huruf terakhir yang identik (I COEIC), dalam aksara Yunani kuno, huruf awal keduanya memiliki bentuk yang hampir sama (Omicron - O dan Sigma - C). Selain itu, huruf $\Pi$ juga berpotensi menimbulkan kerancuan, mengingat kemiripannya dengan kombinasi ГI (Gamma dan Iota). Kedua, kata ỏ $\gamma 1 \sigma \theta \varepsilon i ́ s$ muncul sebanyak empat kali dalam literatur biblikal (Kel. 32:19; Ul. 6:15; Mat. 18:34; Luk. 14:21) dan satu kali dalam Apokrifa (Bel. 1:21, versi Theodo-

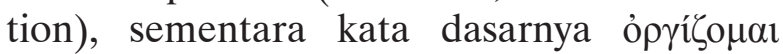
merupakan kata yang banyak dipakai dalam beragam literatur Yunani. Ini jauh berbeda dengan $\sigma \pi \lambda \alpha \gamma \chi \nu 1 \sigma \theta \varepsilon i \varsigma s$ yang muncul hanya tiga kali dalam Perjanjian Baru (Mat. 18:27; 20:34; Mrk. 9:22). Bahkan kata dasarnya, $\sigma \pi \lambda \alpha \gamma \chi v i ́ \zeta o \mu \alpha 1$, tidak pernah dipakai selain dalam Perjanjian Baru. Dengan kata lain, kata ỏ $\gamma \imath \sigma \theta \varepsilon i ́ s$ dan variasinya merupakan kata yang jauh lebih dikenal dan lebih banyak digu-

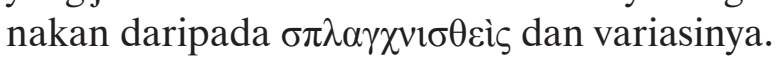

Sederhananya, Williams berpendapat bahwa karena alasan kesilapan, penyalin mengganti

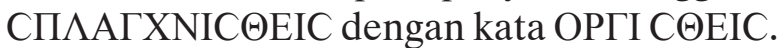
Penyalin yang melihat СП ААГXNIC $\Theta E I C$ berpikir bahwa kata tersebut adalah kata

\footnotetext{
${ }^{36}$ Ebojo berpendapat bahwa proposal Williams memang bisa jadi benar. Akan tetapi, ia tidak sependapat dengan Williams dan melihat proposalnya terlalu rumit serta mengasumsikan banyak ketidaksengajaan. Dari persepektif palaeografis, ia berpendapat bahwa lebih tepat memahami perubahan ini sebagai perubahan yang disengaja, ketimbang perubahan yang tidak disengaja. Sama seperti mayoritas sarjana, Ebojo sendiri membela orisina-

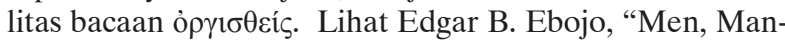
uscripts, and Mercy: Searching a Merciful God amongst the Variants," 7-8, n. 37. Penulis tidak terlalu sependapat dengan Ebojo, sebab beberapa studi menunjukkan bahwa kecenderungan para penyalin naskah Perjanjian Baru ialah memperpendek dan mengubah dengan tidak sengaja. Lihat misalnya karya penting James Royse, Scribal Habits in Early Greek New Testament Papyri, NTTSD 36 (Leiden: Brill, 2008).

${ }^{37}$ Williams, "An Examination of Ehrman's Case for

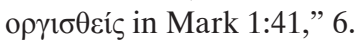


ОРГІ С $\Theta E I C$, yang bukan hanya berbentuk mirip tetapi juga jauh lebih dikenal diban-

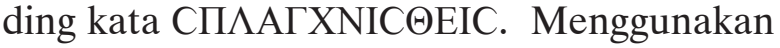
analogi dari bahasa Indonesia modern (meski tentu saja tidak sempurna), ini sama seperti seseorang yang kesulitan membedakan kata PEMBAHASAAN dan PEMBAHASAN. Dalam pengalaman pribadi penulis, beberapa kali penulis mendapati orang-orang yang salah menyalin kata "pembahasaan" menjadi "pembahasan." Kedua kata ini mirip dan hanya dibedakan oleh sebuah huruf 'a.' Akan tetapi, karena kata 'pembahasan' jauh lebih sering digunakan ketimbang 'pembahasaan,' maka bisa dipahami bila banyak orang secara otomatis mengubah kata yang jarang dipakai (pembahasaan) menjadi kata yang lebih dikenal (pembahasan). ${ }^{38}$

\section{Kesimpulan}

Diskusi mengenai teks Markus 1:41 merupakan diskusi teks yang menarik. Mayoritas sarjana menolak keutamaan bacaan $\sigma \pi \lambda \alpha \gamma \chi \nu i \sigma \theta \varepsilon \grave{\varsigma} \varsigma$ dengan dasar argumen internal. Akan tetapi, bukti eksternal ternyata sangat kuat mendukung keutamaan bacaan tersebut. Bacaan ini dimiliki oleh naskah-naskah

\footnotetext{
${ }^{38}$ Ibid., 7-8. Meski demikian, penulis melihat bahwa sebenarnya ada satu potensi problem dalam analisis Williams, yakni bahwa proposalnya mengasumsikan pengenalan yang komprehensif terhadap literatur masa itu. Nyatanya, tidak semua literatur masa itu tersisa hingga hari ini, sehingga tidak bisa dipastikan apakah $\sigma \pi \lambda \alpha \gamma \chi \nu 1 \sigma \theta \varepsilon i \varsigma$

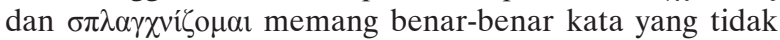
pernah dipakai di luar Perjanjian Baru. Seandainya dalam beberapa waktu ke depan diketemukan ratusan literatur Yunani kuno baru yang mengandung kata $\sigma \pi \lambda \alpha \gamma \chi v i \sigma \theta \varepsilon i \varsigma$ dan $\sigma \pi \lambda \alpha \gamma \chi v i \zeta{ }^{\prime} \mu_{\alpha 1}$ (sehingga artinya, kedua kata ini muncul dalam frekuensi yang lebih tinggi), maka proposal Williams perlu dikaji ulang dengan serius.
}

yang lebih awal dan berkualitas baik, serta bisa ditemukan lintas kluster. Ini sangat ber-

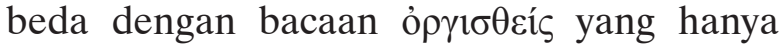
didukung oleh segelintir saksi dari kluster D. Selain itu, analisis pregenealogical coherence makin memperkuat konklusifitas bukti eksternal ini: koherensi antarsaksi yang mendukung bacaan $\sigma \pi \lambda \alpha \gamma \chi v i \sigma \theta \varepsilon i \varsigma$ ternyata jauh lebih kuat dibanding saksi yang mendukung

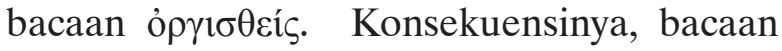
$\sigma \pi \lambda \alpha \gamma \chi \nu 1 \sigma \theta \varepsilon i \zeta$ merupakan bacaan yang sangat mungkin ditransmisikan dengan baik. Oleh karena itu, bukti eksternal yang sangat kuat ini tidak boleh diabaikan begitu saja. Terkait bukti internal, penulis melihat bahwa sampai sejauh ini proposal Williams merupakan solusi terbaik untuk menjelaskan perubahan

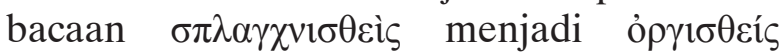
(meski memang harus diakui bahwa proposal ini menyimpan sebuah potensi problem; lihat catatan kaki 38). Karena itu, sampai dengan ditemukannya bukti baru, penulis melihat bahwa keputusan editor $\mathrm{NA}^{28}$, $\mathrm{UBS}^{5}$, dan Tyndale House Greek New Testament (THGNT) untuk tetap mencantumkan $\sigma \pi \lambda \alpha \gamma \chi v i \sigma \theta \varepsilon i \varsigma$ dalam teks kritikal mereka adalah keputusan yang tepat! 


\section{Daftar Kepustakaan}

Black, David A. ed. Rethinking New Testament Textual Criticism. Grand Rapids: Baker, 2002.

Brooks, James A. Mark. NAC. Nashville: Broadman \& Holman, 2001.

Ebojo, Edgar B. "Men, Manuscripts, and Mercy: Searching a Merciful God amongst the Variants," 1-12 (makalah yang tidak diterbitkan, disampaikan dalam Bible Research Seminar di AGST Filipina 2016).

Edwards, James R. The Gospel According to Mark. PNTC. Grand Rapids/Leicester: Eerdmans/ Apollos, 2002.

Ehrman, Bart D. Misquoting Jesus: The Story behind Who Changed the Bible and Why. San Francisco: HarperSanFrancisco, 2005.

. "A Leper in the Hand of an Angry Jesus." Dalam Studies in the Textual Criticism of the New Testament. Leiden: Brill, 2006.

Ehrman, Bart D. dan Michael W. Holmes, eds., The Text of the New Testament in Contemporary Research: Essays on the Status Quaestionis. NTTSD 42. Leiden: Brill, 2013.

Ellingworth, Paul. "Text, Translation, and Theology: The New Testament in the Original Greek?" Filologia Neotestamentaria 13, no. 25-26 (2000): 61-73

Epp, Eldon J. “The Twentieth Century Interlude in New Testament Textual Criticism,” Journal of Biblical Literature 93 (1974): 386-414.

. "Multivalence of the Term 'Original Text' in New Testament Textual Criticism," Harvard Theological Review 92 (1999): 245-81

Epp, Eldon J. dan Gordon D. Fee. Studies in the Theory and Method of New Testament Textual Criticism. Grand Rapids: Eerdmans, 1993.

France, R.T. The Gospel of Mark. NIGTC. Grand Rapids/Carlisle: Eerdmans/Paternoster, 2002.

Hooker, Morna D. The Gospel According to Saint Mark. BlackNTC. Peabody: Hendrickson, 1991.

Hurtado, Larry W. Mark. NIBC. Peabody: Hendrickson, 1989.

Kristianto, Stefanus. "Resensi Buku A New Approach to Textual Criticism: An Introduction to the Coherence-Based Genealogical Coherence," Jurnal Theologia Aletheia (terbit September 2018).

Marcus, Joel. Mark 1-8: A New Translation with Introduction and Commentary. AnchorBib; New Haven/London: YUP, 2008.

Metzger, Bruce M. A Textual Commentary on the Greek New Testament 2nd Edition. London/New York: UBS, 1994.

Parker, David C. The Living Text of the Gospels. Cambridge: CUP, 1997. . Textual Scholarship and the Making of the New Testament. Oxford: OUP, 2012.

Royse, James. Scribal Habits in Early Greek New Testament Papyri. NTTSD 36. Leiden: Brill, 2008. 
Tan Kim Huat. The Gospel According to Mark. Asia Bible Commentary. Manila: Asia Theological Association, 2011.

Wachtel, Klaus dan Michael W. Holmes, eds. The Textual History of the Greek New Testament: Changing Views in Contemporrary Research. Atlanta: SBL, 2011.

Wallace, Daniel B. "The Gospel According to Bart: A Review Article of Misquoting Jesus by Bart Ehrman,” Journal of the Evangelical Theological Society 49, no. 2 (2006): 327-49.

. "Challenges in New Testament Textual Criticism for the Twenty-First Century," Journal of Evangelical Theological Society 52, no. 1 (March 2009): 79-100.

Wasserman, Tommy dan Peter Gurry. A New Approach to Textual Criticism: An Introduction to the Coherence-Based Genealogical Method (Atlanta/Stuttgart: SBL/Deutsche Bibelgesellschaft, 2017)

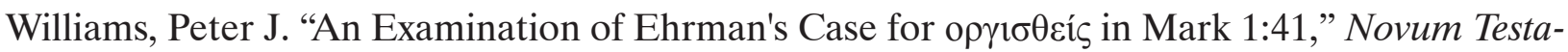
mentum 54 (2012): 1-12 